\title{
The consumption of non-alcoholic beverages and the occurrence of dental erosion among a group of adults visiting dental practices in Krakow
}

\author{
Beata Piórecka ${ }^{1}$ (1) https://orid.org0000-0001-7323-4797 \\ Patrycja Sobczak ${ }^{1}$ (1) https://orid.org/000-0002-4155-6668 \\ Bożena Muszyńska² ${ }^{2}$ (1) htps://orid.org/0000-0002-5007-1486 \\ Paweł Jagielski ${ }^{1}$ (D) htps://orid.org/0000-0001-7583-8965 \\ Małgorzata Schlegel-Zawadzka ${ }^{1}$ (1) https://orid.org/0000-0002-2958-4658
}

\begin{abstract}
${ }^{1}$ Department of Human Nutrition, Institute of Public Health, Faculty of Health Sciences Jagiellonian University Medical College

${ }^{2}$ Chair and Department of Pharmaceutical Botany, Faculty of Pharmacy, Jagiellonian University Medical College
\end{abstract}

Address for correspondence: Beata Piórecka, Instytut Zdrowia Publicznego, ul. Grzegórzecka 20, 31-531 Kraków, beata.piorecka@uj.edu.pl

\section{Abstract}

The aim of the study was to assess correlations between the consumption of selected non-alcoholic beverages and the prevalence of tooth erosion among adults visiting dental practices in Krakow. Dental erosion in group 124 people aged 18-55 was assessed using BEWE, while oral dryness with a mirror test. FFQ was used to assess fluid intake, supplemented with questions regarding oral hygiene and socio-demographic factors. Dental erosion, mostly mild, was found in $38.7 \%$ of participants. Dry mouth (second and third degree in a mirror test) concerned $16.1 \%$ of subjects. Dental erosion was significantly more common $(p=0.01)$ among participants with dry mouth. More frequent consumption of sweetened beverages as well as $100 \%$ juices (fruit, vegetable) correlated with dental erosion. Overall consumption of such beverages and also milk, as well as daily fluid intake was significantly higher among subjects with dental erosion.

Incorrect behaviors regarding the quality and quantity of drinks may contribute to tooth erosion among adults.

\section{Key words: dental erosion, consumption of non-alcoholic heverages, total fluid intake, adults}

Stowa kiuczowe: erozja zę̧ów, spożycie napojów bezalloholowych, pobranie ptynów, osoby dorosie

Przygotowanie do wydania elektronicznego finansowane w ramach umowy

i Szkolnictwa Wyższego

641/P-DUN/2018 ze środków Ministra Nauki i Szkolnictwa Wyższego

przeznaczonych na działalność upowszechniającą naukę.

\section{Introduction}

Dental erosion, understood as loss of hard tissue (enamel, dentine, root cement), is a progressive and irreversible loss of non-carious origin, which arises due to the interaction of acids on teeth surface. Besides aesthetic consequences, its occurrence also affects oral health hypersensitivity and the potential loss of damaged teeth, associated with the inflammation of the pulp (pulpitis), periapical tissues or greater probability of post-traumatic lesions affected by erosion. The formation of dental erosion is dependent on many external and internal factors. The latter include the following: the structure of teeth, the amount and structure of secreted saliva and the course of some diseases, such as the gastro-esophageal reflux, or the occurrence and severity of vomiting. The main external factor conducive to dental erosion is the lifestyle, particularly the nutritional behaviour associated with the consumption of (carbonated and noncarbonated) non-alcoholic beverages [1].

Erosion is caused by solutions of acids that come into contact with the teeth. It is assumed that any type of fluid 
and food, whose $\mathrm{pH}$ reaches a critical value for enamel (estimated to be 5.5 or lower), may be a potential cause of erosion [2]. The occurrence and severity of erosive lesions depend on how long and how frequently the damaging factor appears in the oral cavity [3].

In the case of beverages, the way they are ingested is important. The risk of erosion is lower when drinks are swallowed in large gulps rather than slowly sipped for a long time. Holding $\mathrm{pH}$-reducing drinks in the mouth before swallowing them increases the risk of erosion. Numerous clinical studies have shown that the risk of erosion is reduced when beverages are drunk through a straw arranged on the palate. However, if the straw is placed on the teeth, it may lead to the erosion of the incisors [4].

Non-alcoholic beverages that are particularly conducive to erosion include: energy drinks and sports drinks (as they contain citric acid, malic acid, sodium citrate and potassium citrate), carbonated drinks (citric, carbonic, orthophosphoric and ascorbic acids), as well as some citrus juices $[5,6]$. The frequency of consuming coffee and dietary supplements containing vitamin $\mathrm{C}$ and iron, as well as alcoholic beverages can also be important in the development of dental erosion. It is indicated that chilled beverages show a greater erosion-conducive effect, and the risk of erosion is further increased when they are consumed in the evening [7]. The damaging effect on enamel is greater in the case of fruit drinks and juices than fruit pulps or whole fruits [8].

Potential erosive capacity of beverages or foods does not only depend on their $\mathrm{pH}$ value, but also on the type of acid and its concentration, chelation properties, as well as the content of beneficial calcium, phosphate and fluoride ions, which support the remineralization of teeth. The erosion-conducive drinks mentioned above contain citric acid, which due to its chelation properties binds calcium, further increasing the risk of erosion by reducing the amount of calcium in the saliva [9].

It is believed that the buffer capacity of saliva plays a greater role in the prevention of erosion than caries. Its action consists in the neutralization of acids, formation of acquired casings and remineralization, which may affect the course of erosion [10].

What should also be considered is the daily amount of consumed fluids and how the hydration of the body impacts the amount of saliva. In the case of dehydration, the flow of saliva decreases, while at the appropriate level of hydration, salivation increases [11].

If the consumed food contains the recommended intake of vegetables and fruit, you can deliver to the body about $20-25 \%$ of the daily water demand. The remaining part of the demand is supplemented by the daily drinking of the properly selected quantity and quality of liquids. In highly industrialized countries, the intake of liquids is observed to be too low, which is especially true for children, but also for adults. This was confirmed in cross-sectional studies (Liq.in project), where only $51 \%$ of all adults, from different countries participating in the study, met the recommendations of the adequate (AI - Adequate Intake) daily water intake as recommended by the European Food Safety Authority (EFSA) [12].
According to various studies, certain non-alcoholic beverages, including sweetened carbonated and non-carbonated beverages, energy drinks and isotonic drinks, are increasingly consumed in Poland. This applies, in particular, to teenage groups and young active adults [13, 14].

The aim of the work is a qualitative and quantitative assessment of the consumption of non-alcoholic beverages in relation to the prevalence and assessment of the severity of erosive defects in the group of adults visiting dental practices in Kraków, taking into account the way in which the clinic functions.

\section{Material and method}

The study included 124 people aged $18-55$ years who in the period of March-August 2017 visisted dental practices in Kraków, including 2 practices that provided services on a commercial basis and one practice which had a contract with the National Health Fund (pol. NFZ). The participants included person who came in to have their dental check-up or to undergo dental treatment, and agreed to participate in the proposed study. The inclusion criteria included: age, residence in Kraków and informed written consent for participation in the study. The study was conducted taking into account ethical principles in the field of conducting medical examinations contained in the Helsinki Declaration [15].

Selected nutritional behaviours, including fluid intake, were assessed using a qualitative and quantitative Food Frequency Questionnaire (FFQ), supplemented with questions about oral hygiene and the socio-demographic situation of the subjects. The subjects were also asked to enter the current height and weight, based on which the Body Mass Index (BMI) was calculated and interpreted, according to the WHO criteria [16].

In the assessment of the volume of fluid intake, respondents were asked to mark the number of glasses of beverages consumed per day, and it was determined that one glass was about $200 \mathrm{ml}$ of fluid, which allowed to estimate the daily consumption of selected non-alcoholic beverages.

The advancement of erosive lesions was assessed during the planned dental assessment, and performed by a dentist using the BEWE (Basic Erosive Wear Examination) indicator, while the oral cavity dryness was assessed using a mirror test (grade I-III). In grade I, the mirror moves freely over the mucous membrane, a small resistance is noticed in grade II, while in grade III the mirror clings to the mucous membrane [17].

When calculating the BEWE index, the teeth were divided into sextants (first sextant - teeth 17-14, second sextant - teeth 13-23, third sextant - teeth 24-27, fourth sextant $-37-34$, fifth sextant - teeth 33-43, sixth sextant - teeth 44-47). The study included all natural teeth (with the exception of third molars - teeth 18, 28, 38, 48). For each studied sextant, the highest value is recorded and then added together. This cumulative value illustrates the risk of erosion and is defined as $0-2-$ no risk (grade 1), 3-8 - low risk (grade 2), 9-13 - moderate risk (grade 3 ), and $\geq 14-$ high risk (grade 4) [18]. 
Using the Statistica 12.0 PL programme, statistical analyses of coded respondents' answers and results regarding the occurrence and severity of dental erosion and oral dryness were performed. Using the Mann-Whitney $\mathrm{U}$ test, statistical analyses were carried out that included dividing the respondents by sex and age (group I - persons aged $18-35.9$ years and group II: $36-55$ years) and by the form of operation of the dental practice (private practice and practice implementing the $N F Z$ contract), and also taking into account the occurrence of dry mouth, and the assessment of dental erosion according to the BEWE indicator (group A - no risk, group B - small, moderate, large risk). The significance level $\alpha=0.05$ was assumed in order to verify the differences in the respondents' answers.

\section{Resullts}

The study group consisted of 124 people, of whom 63 $(50.8 \%)$ were private patients, and the remaining patients participated in treatment in dental practices guaranteed by the NFZ. Nearly two-thirds of the respondents $(66.1 \%)$ were female. The average age for all study participants was $35.85+10.54$ years. There were no significant differences in the age of the respondents de- pending on the gender and the form of operation of the dental practice (private/public). The socio-demographic characteristics and nutritional status of the study group in general and depending on the form of functioning of the dental practice are shown in Table I. Only $27.4 \%$ of Kraków residents included in the study declared a high level of physical activity. According to BMI interpretation by gender, $73 \%$ of women had normal body mass, whereas $64.3 \%$ of men participating in the study were overweight $(p<0.01)$. Respondents were asked about the diseases that may affect the development of tooth erosion. The majority of respondents most often reported the gastroesophageal reflux disease $(6.5 \%)$ and diabetes $(4.0 \%)$. Only few pointed out the occurrence of eating disorders $(1.6 \%)$, inflammation of salivary glands $(1.6 \%)$, as well as xerostomia (dry mouth) $(0.8 \%)$ and gastric ulcer $(0.8 \%)$. Any dental hypersensitivity did not report $41 \%$ respondents and $38.7 \%$ reported occasional hypersensitivity. About a third of all respondents $(29.8 \%)$ reported that they are currently taking dietary supplements, of which $15.3 \%$ used vitamin C, and only 2 persons reported taking iron.

The occurrence of dental erosion was determined in $38.7 \%$ of all examined persons, and these were mostly lesions of low advancement. Figure 1 shows the oc-

\begin{tabular}{|c|c|c|c|c|}
\hline Socio-demographic factors studied & $\begin{array}{c}\text { Total } \\
n=124 \\
{[\%]}\end{array}$ & $\begin{array}{c}\text { Private patients } \\
\begin{array}{c}n=63 \\
{[\%]}\end{array}\end{array}$ & $\begin{array}{c}\text { Public }(N F Z) \\
\text { patients } \\
n=61 \\
{[\%]}\end{array}$ & $p$ \\
\hline $\begin{array}{l}\text { Sex } \\
\text { Female } \\
\text { Male }\end{array}$ & $\begin{array}{l}66.1 \\
33.9\end{array}$ & $\begin{array}{l}63.5 \\
36.5\end{array}$ & $\begin{array}{l}68.9 \\
31.1\end{array}$ & 0.5283 \\
\hline $\begin{array}{l}\text { Education } \\
\text { Vocational } \\
\text { Secondary } \\
\text { Higher }\end{array}$ & $\begin{array}{r}8.1 \\
40.3 \\
51.6 \\
\end{array}$ & $\begin{array}{r}7.9 \\
38.1 \\
54.0 \\
\end{array}$ & $\begin{array}{r}8.2 \\
42.6 \\
49.2 \\
\end{array}$ & 0.8616 \\
\hline $\begin{array}{l}\text { Material situation } \\
\text { Poor } \\
\text { Sufficient } \\
\text { Good } \\
\text { Very good } \\
\end{array}$ & $\begin{array}{r}0.8 \\
52.4 \\
41.9 \\
4.8\end{array}$ & $\begin{array}{r}1.6 \\
47.6 \\
41.3 \\
9.5\end{array}$ & $\begin{array}{r}0.0 \\
57.4 \\
42.6 \\
0.0\end{array}$ & 0.0614 \\
\hline $\begin{array}{l}\text { Professionally active } \\
\text { No } \\
\text { Yes }\end{array}$ & $\begin{array}{l}13.7 \\
86.3\end{array}$ & $\begin{array}{l}23.8 \\
76.2\end{array}$ & $\begin{array}{r}3.3 \\
96.7\end{array}$ & 0.0009 \\
\hline $\begin{array}{l}\text { Declared level of physical activity } \\
\text { Low } \\
\text { Average } \\
\text { High }\end{array}$ & $\begin{array}{l}20.2 \\
52.4 \\
27.4\end{array}$ & $\begin{array}{l}20.6 \\
50.8 \\
28.6\end{array}$ & $\begin{array}{l}19.7 \\
54.1 \\
26.2\end{array}$ & 0.9320 \\
\hline $\begin{array}{l}\text { Nutritional status according to BMI } \\
\text { Underweight }\left(<18.5 \mathrm{~kg} / \mathrm{m}^{2}\right) \\
\text { Normal body weight }\left(18.5-24.9 \mathrm{~kg} / \mathrm{m}^{2}\right) \\
\text { Overweight }\left(25-29.9 \mathrm{~kg} / \mathrm{m}^{2}\right) \\
\text { Obesity }\left(\geq 30 \mathrm{~kg} / \mathrm{m}^{2}\right)\end{array}$ & $\begin{array}{r}3.2 \\
57.3 \\
33.9 \\
5.6\end{array}$ & $\begin{array}{r}0.0 \\
57.1 \\
36.5 \\
6.3\end{array}$ & $\begin{array}{r}6.6 \\
57.4 \\
31.1 \\
4.9\end{array}$ & 0.7214 \\
\hline
\end{tabular}

$p$ - statistical significance, $n$ - number of subjects

Table I. Socio-demographic characteristics and nutritional status of the study group in general and depending on the type of dental practice.

Source: Own elaboration. 


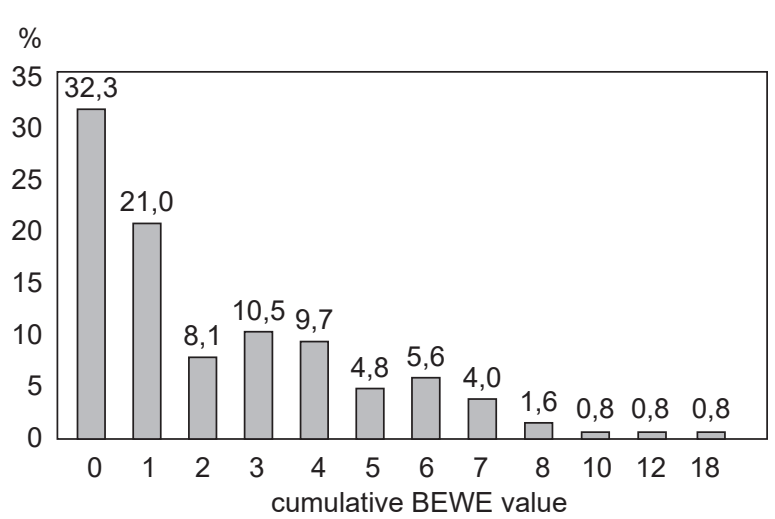

Figure 1. Distribution of the cumulative BEWE value for all subjects.

Source: Own elaboration.

currence of dental erosion according to the cumulative BEWE value for all subjects. Only in the case of 3 person, a moderate and high risk of severity of erosion was determined, i.e. grades 3 and 4 according to the BEWE interpretation.

There was no statistically significant difference between the occurrence and severity of erosive lesions among patients depending on the type of the dental practice. In the group of people who reported to the $N F Z$ practice (61 people), the average value of the cumulative BEWE coefficient was $2.51+2.63$, and in the group of private patients (63 people) - the average cumulative BEWE value was equal to $2.27+3.10$. The differentiation of erosive defects depending on the sex and age of the examined persons was also assessed. In the case of women, the average BEWE ratio was $2.30+2.98\left(M_{e}=1\right)$, and among men $-2.55+2.67\left(M_{e}=1.5\right)$, not amounting to a statistically significant difference $(p=0.47)$.

There was no statistically significant difference $(p=0.45)$ in the occurrence and severity of erosion depending on age. In the first age group, the average cumulative BEWE value was $2.19+2.82$, while in the second group it was insignificantly higher and amounted to 2.61
+2.93 . The declared level of physical activity was also not associated with erosion in the study groups $(p=0.42)$.

Table II presents interpretations of the BEWE indicator depending on the type of the dental practice. Dental erosion was found in $42.6 \%$ of respondents receiving treatment in an NFZ dental practice, and in $34.9 \%$ of respondents receiving private treatment, but it was not statistically significant difference.

It was confirmed that the frequency of consumption of sweetened carbonated and non-carbonated drinks as well as $100 \%$ fruit and/or vegetable juice was associated with dental erosion and the degree of its advancement. Declared frequency of consumption of selected non-alcoholic beverages depending on the occurrence of dental erosion is presented in Table III. The subjects in whom tooth erosion was determined also consumed more of the above mentioned erosion-conducive beverages, as well as milk and/or milk drinks, and their daily fluid intake was significantly higher compared to people without dental erosion, as shown in Table IV.

Over $75 \%$ of respondents declared that they do not use a straw when drinking beverages, which is considered preventive against erosive defects, but $21.8 \%$ sometimes use it, and only 3 people reported that they regularly drink through a straw.

Dry mouth defined as the second and third degree in the mirror test classification concerned $16.1 \%$ of all subjects. $67.3 \%$ of persons in the group with normal moisturization of the oral mucosa did not have dental erosion. Among people with dry mouth, dental erosion was significantly more common ( $70 \%$ of subjects) and was more severe (according to BEWE: grade $2=60 \%$, grade $3=5 \%$, grade $4=5 \%$ ) compared to people who did not suffer from dry mouth $(p=0.01)$.

The occurrence of dry mouth was associated with the amount of total fluids taken $(p<0.01)$. People who experienced dry mouth drank more fluids during the day. The causes of oral dryness were not examined. As many as $25.8 \%$ of participants in the survey admitted that they are struggling with the feeling of dry mouth, with $11.3 \%$ experiencing dryness several times a week, and $12.9 \%$ of respondents indicating that they experience it most often in the morning.

\begin{tabular}{|l|c|c|c|c|c|c|}
\hline \multirow{2}{*}{$\begin{array}{c}\text { BEWE-based interpretation of } \\
\text { dental erosion }\end{array}$} & \multicolumn{2}{|c|}{ Total } & \multicolumn{2}{c|}{$\begin{array}{c}\text { Private patients } \\
\mathbf{n}=\mathbf{6 3}\end{array}$} & \multicolumn{2}{c|}{$\begin{array}{c}\text { Public (NFZ) patients } \\
\mathbf{n}=\mathbf{6 1}\end{array}$} \\
\cline { 2 - 7 } & $\mathbf{n}$ & $\mathbf{0}$ & $\mathbf{n}$ & $\mathbf{\%}$ & $\mathbf{n}$ & $\mathbf{\%}$ \\
\hline Grade 1 - no risk & 76 & 41 & 41 & 65.1 & 35 & 57.4 \\
\hline Grade 2- low risk & 45 & 21 & 21 & 33.3 & 24 & 39.4 \\
\hline Grade 3- moderate risk & 1 & 0 & 0 & 0 & 1 & 1.6 \\
\hline Grade 4- high risk & 2 & 1 & 1 & 1.6 & 1 & 1.6 \\
\hline
\end{tabular}

$n$ - number of subjects

Table II. Occurrence and severity of erosive defects in the study group in general and depending on the type of dental practice. Source: Own elaboration. 


\begin{tabular}{|c|c|c|c|c|c|c|c|c|c|c|c|}
\hline \multirow[b]{2}{*}{ Non-alcoholic beverages } & \multicolumn{5}{|c|}{$\begin{array}{l}\text { No dental erosion } \\
\quad n=76\end{array}$} & \multicolumn{5}{|c|}{$\begin{array}{c}\text { Risk of erosion } \\
\text { (low, moderate, high) } \\
n=48\end{array}$} & \multirow[b]{2}{*}{$p$} \\
\hline & $\frac{\bar{e}}{\dot{\bar{b}}}$ & 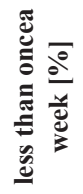 & 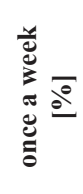 & 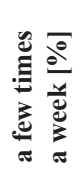 & $\frac{\overline{0}}{\frac{\overline{0}}{2}}$ & $\frac{\bar{d}}{\frac{\bar{d}}{\grave{D}}}$ & 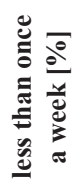 & 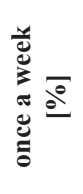 & 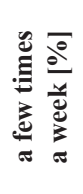 & $\begin{array}{l}\frac{\bar{e}}{2} \\
\frac{\vec{a}}{0} \\
\frac{\overrightarrow{0}}{0} \\
\overrightarrow{0}\end{array}$ & \\
\hline Water & 0.0 & 0.0 & 1.3 & 7.9 & 90.8 & 0.0 & 2.1 & 0.0 & 16.7 & 81.3 & 0.3748 \\
\hline $100 \%$ fruit/vegetable juices & 19.7 & 25.0 & 19.7 & 30.3 & 5.3 & 8.3 & 16.7 & 25.0 & 39.6 & 10.4 & 0.0316 \\
\hline $\begin{array}{l}\text { Sweetened non-carbonated } \\
\text { beverages (including flavoured } \\
\text { waters) }\end{array}$ & 60.5 & 18.4 & 11.8 & 6.6 & 2.6 & 37.5 & 16.7 & 10.4 & 29.2 & 6.3 & 0.0039 \\
\hline $\begin{array}{l}\text { Sweetened carbonated beverages } \\
\text { (e.g. cola) }\end{array}$ & 42.1 & 22.4 & 21.1 & 14.5 & 0 & 22.9 & 33.3 & 14.6 & 22.9 & 6.3 & 0.0392 \\
\hline Black tea & 14.5 & 2.6 & 13.2 & 17.1 & 52.6 & 20.8 & 6.3 & 8.3 & 31.3 & 33.3 & 0.0986 \\
\hline Fruit tea & 43.4 & 7.9 & 10.5 & 22.4 & 15.8 & 39.6 & 20.8 & 8.3 & 22.9 & 8.3 & 0.6535 \\
\hline Coffee & 25.0 & 3.9 & 0.0 & 7.9 & 63.2 & 4.2 & 2.1 & 8.3 & 18.8 & 66.7 & 0.3247 \\
\hline Energy drinks & 76.3 & 17.1 & 3.9 & 1.3 & 1.3 & 62.5 & 22.9 & 10.4 & 4.2 & 0 & 0.1716 \\
\hline Isotonic drinks & 84.2 & 9.2 & 2,6 & 3.9 & 0 & 64.6 & 18.8 & 10.4 & 4.2 & 2.1 & 0.0648 \\
\hline Milk and/or milk drinks & 21.1 & 11.8 & 9.2 & 34.2 & 23.7 & 10.4 & 8.3 & 16.7 & 41.7 & 22.9 & 0.4045 \\
\hline
\end{tabular}

$p$ - statistical significance, $n$ - number of subjects

Table III. Frequency of consumption of selected non-alcoholic drinks by the total number of subjects depending on the occurrence of tooth erosion.

Source: Own elaboration.

\begin{tabular}{|c|c|c|c|c|c|c|c|}
\hline \multirow[t]{2}{*}{ Beverages $[\mathrm{ml}]$} & \multicolumn{3}{|c|}{$\begin{array}{c}\text { No erosion risk } \\
\quad n=76\end{array}$} & \multicolumn{3}{|c|}{$\begin{array}{c}\text { Risk of erosion } \\
\text { (low, moderate, high) } \\
n=48\end{array}$} & \multirow[t]{2}{*}{$p$} \\
\hline & $\mathbf{X}$ & SD & Me & $\mathbf{X}$ & SD & Me & \\
\hline Water & 805.26 & 405.26 & 800.00 & 858.33 & 408.34 & 800.00 & 0.4822 \\
\hline $100 \%$ fruit/vegetable juices & 200.00 & 235.51 & 200.00 & 279.17 & 217.29 & 200.00 & 0.0160 \\
\hline $\begin{array}{l}\text { Sweetened non-carbonated } \\
\text { beverages (including flavoured } \\
\text { waters) }\end{array}$ & 55.26 & 111.23 & 0.00 & 187.50 & 258.99 & 200.00 & 0.0031 \\
\hline $\begin{array}{l}\text { Sweetened carbonated beverages } \\
\text { (e.g. cola) }\end{array}$ & 139.47 & 206.61 & 0.00 & 237.50 & 239.35 & 200.00 & 0.0145 \\
\hline Black tea & 389.47 & 323.14 & 400.00 & 404.17 & 427.74 & 200.00 & 0.6026 \\
\hline Fruit tea & 168.42 & 228.74 & 100.00 & 145.83 & 217.29 & 0.00 & 0.6152 \\
\hline Coffee & 289.47 & 227.20 & 200.00 & 350.00 & 220.25 & 400.00 & 0.1480 \\
\hline Energy drinks & 50.00 & 118.32 & 0.00 & 70.83 & 127.09 & 0.00 & 0.3790 \\
\hline Isotonic drinks & 39.47 & 103.38 & 0.00 & 100.00 & 184.51 & 0.00 & 0.1270 \\
\hline Milk and/or milk drinks & 231.58 & 284.82 & 200.00 & 316.67 & 299.88 & 200.00 & 0.0354 \\
\hline TOTAL BEVERAGES [ml] & 2368.42 & 888.48 & 2200.00 & 2950.00 & 1008.47 & 3000.00 & 0.0023 \\
\hline
\end{tabular}

$p$ - statistical significance, $n$ - number of subjects

Table IV. The daily amount of non-alcoholic beverages consumed in the study group depending on the occurrence of tooth erosion. Source: Own elaboration. 


\begin{tabular}{|l|c|c|c|c|}
\hline \multicolumn{1}{|c|}{ Oral hygiene products used } & $\begin{array}{c}\text { Total } \\
\mathbf{n = 1 2 4} \\
{[\mathbf{\%}]}\end{array}$ & $\begin{array}{c}\text { Private patients } \\
\boldsymbol{n = 6 3} \\
{[\mathbf{\%}]}\end{array}$ & $\begin{array}{c}\text { Public (NFZ) patients } \\
\boldsymbol{n = 6 1} \\
{[\mathbf{\%}]}\end{array}$ & $\boldsymbol{p}$ \\
\hline Electric toothbrush & 46.8 & 54.0 & 39.3 & 0.1028 \\
\hline Interdental brushes & 23.4 & 25.4 & 21.3 & 0.5911 \\
\hline Manual toothbrush & 66.9 & 63.5 & 70.5 & 0.4075 \\
\hline Dental floss & 54.0 & 41.3 & 67.2 & 0.0038 \\
\hline Liquid mouthwash & 61.3 & 65.1 & 57.4 & 0.3787 \\
\hline Oral irrigator & 4.0 & 1.6 & 6.6 & 0.1596 \\
\hline
\end{tabular}

$p$-statistical significance, $n$ - number of subjects

Table V. Methods of maintaining oral hygiene applied by participants of the study, depending on the type of dental practice. Source: Own elaboration.

The survey also included questions about oral hygiene (Table V). Over $80 \%$ of people declared brushing their teeth at least twice a day, $66.9 \%$ reported using a manual toothbrush, and $46.8 \%$ an electric toothbrush. Only $54 \%$ of all respondents use floss to clean interdental spaces, significantly more often this hygiene measure was used by patients of $N F Z$ facilities $(p<0.01)$ compared to patients attending private practices, and $61.3 \%$ of all subjects use oral hygiene liquid. Only 6 people brush their teeth immediately after a meal and just over $20 \%$ regularly chew sugar-free chewing gum after a meal.

\section{Discussion}

The loss of tooth tissue as a result of erosion has been recognized by the European Federation of Conservative Dentistry (EFCD) as a significant problem in population health, which has a great impact on everyday dental practice, requiring a more detailed examination and development of criteria for undertaking action [4].

In the European Escarcel study conducted in seven countries in a group of 3,185 people aged $18-35$, no erosion, i.e. value 0 according to BEWE, was determined for $42.9 \%$ of respondents. The remaining group of patients were affected by changes that did not exceed $50 \%$ of the tooth surface, i.e. $27.7 \%(\mathrm{BEWE}=1)$ and $26.1 \%(\mathrm{BEWE}$ $=2$ ). In total, erosive lesions were identified in $29 \%$ of the study Europeans. In contrast, hypersensitivity of teeth was reported by as many as $41.9 \%$ of all subjects, and the link between its occurrence and the consumption of energy drinks and fruit / fruit juices was demonstrated [19].

Most national studies on the prevalence of dental erosion present data concerning children and adolescents [7], while adults are rarely examined and different criteria are used to assess the prevalence of erosive lesions.

In a study conducted in 2012 as part of National Oral Health Monitoring signs of erosion were found in $42.2 \%$ of 1,886 people aged 18 and coming from 7 voivodeships in Poland (based on BEWE). The most common were slight changes (grade 1) - in $28.9 \%$, more severe changes (grade 2) were found in $11.9 \%$ of 18 -year-olds, while grade 3 was observed only in $1.5 \%$ of all subjects. The initial damage to the enamel surface was more common in men $(29.1 \%)$ than in women $(28.6 \%)$, as were other types of lesions. A smaller percentage of people with initial enamel changes was reported among respondents coming from rural areas compared to people living in the city. The highest value of $\mathrm{BEWE}=3(8.3 \%$ of respondents), which is characterized by a greater loss of dental tissue, was found among the youth from the Mazowieckie Voivodeship [20].

In a study conducted among Kraków residents aged 18-55 who attended dental practices, BEWE-established dental erosion was determined for $38.7 \%$ of all subjects, and these were minor lesions. Similarly as in the group of healthy adults in the Kaczmarek and Sołtan study using BEWE indicator [21].

Insignificantly more frequently and more severely, erosive changes related to men, but there were no differences in the occurrence and severity of erosion depending on the age or the declared level of physical activity and the type of functioning of the dental practice. The age of the respondents did not differ depending on the type of the dental practice; the only significant difference was that the patients attending private practices were not in gainful employment.

In the previously mentioned European population study Escarcel, dental erosion changes more often affected inhabitants of rural regions [19].

Observations on the occurrence of non-carious lesions were previosuly made in 1989-1991 among 696 residents of the city of Kraków. In this population study, in which the highest number of participants was between $41-50$ years of age, followed by $31-40$ years and $51-60$ years, only a small percentage of people with non-carious lesions was found, which affected only $1.58 \%$ of all subjects. They occurred mainly in elderly people, and in the 21-30 age group concerned just $3.03 \%$ of the respondents. [22].

The only national study that used BEWE and covered almost all age groups in the field of prevalence of dental erosion was the work carried out by Waszkiel. Erosive lesions were determined in $33.3 \%$ of respondents in $18-24$ 
age group, $19.4 \%$ in the group of $25-30$ age, while in the range of 35-44 years group only for $6.1 \%$ of people [23].

Waszkiel also assessed the impact of diet on the occurrence of dental erosion [24]. She divided the group of 120 healthy subjects aged 18-30 depending on whether they suffered from dental erosion or not, and assessed their eating habits. Citrus juice was consumed several times a day by over $36 \%$ of people with diagnosed dental erosion. A higher percentage of people with clearly more advanced erosion (18\%) admitted more frequent consumption of carbonated beverages than the group without erosion (5\%).

Similar results were obtained in a study conducted among patients of a dental practices in Kraków, where the occurrence of erosive lesions was associated with a higher frequency of consumption of sweetened carbonated and non-carbonated beverages and $100 \%$ fruit and/ or vegetable juices. The limitation of the obtained results is that it is not known whether the consumer consciously chooses $100 \%$ juice, or maybe nectar, or fruit/vegetable drink.

On the basis of research carried out as early as in the 1990s by Jarvinen et al. in Finland, a list of risk factors for tooth erosion was defined, including: drinking cola 4-6 or more times a week, consuming citrus fruits more than twice a day, drinking energizing drinks more often than once a week [25].

Somewhat different conclusions result from the metaanalysis of nine studies conducted by Li et al., carried out among children and adolescents, mainly from Great Britain and Asian countries. They found that there is a statistically significant relationship between the consumption of non-alcoholic beverages (cola type - twice as much chance of erosion) and supplements containing vitamin $\mathrm{C}$ and the occurrence of erosion. However, they did not observe the relationship between the occurrence of erosion and the consumption of fruit juices, isotonic beverages, or milk and yogurts. At the same time, they emphasized that this issue, due to the high epidemiological significance, requires further research, and - due to the small number of studies included in the assessment the meta-analysis may contain conclusions burdened with random error [26].

It is now recognized that beverages with high calcium content, for example milk or calcium-enriched juices, may reduce the risk of dental erosion. Therefore, adequate consumption of milk and dairy products whose $\mathrm{pH}$ is 6.6-6.8, are important in the prevention of dental erosion also among adults [1].

In studies by Ostrowska and Piątowska, it was shown that consumption of isotonic drinks increases the risk of erosive lesions. The study concerned 124 athletes, members of the Academic Sports Association and 103 dentistry students from the Medical Academy in Łódź [27]. In the case of person who are active in sports, there is also the issue of drinking isotonic beverages immediately after physical exercise, in a situation where the secretion of saliva is definitely lower [28]. That is why there are reports that milk can be used as an alternative to athletes in rehydration after physical exercise [29].
Another study, the aim of which was to assess the relationship between food and dental erosion was a study carried out in 2013 in Łódź and Warsaw. This study compared i.a. nutritional behaviour of athletes and students, including those studying dentistry. It was observed that in the group of athletes who ate statistically more apples and drank fruit juices and carbonated drinks, as well as taking vitamins in the form of effervescent tablets, erosion concerned about $30 \%$ of the subjects (in the group of students only $10 \%$ ). The authors pointed out that the results obtained by them are identical to the results of studies carried out by Waszkiel published in 2004, which proved the existence of a direct proportional relationship between tooth erosion and the frequency of drinking carbonated beverages and citrus juices and apple consumption $[24,30]$.

Patients attending dental practices in Kraków diagnosed with dental erosion drank not only more frequently but also more in quantity, i.e. 100\% fruit/vegetable juices, sweetened non-carbonated beverages (including flavoured waters) or sweetened carbonated beverages (e.g. cola), but also milk and/or milk drinks. There was also a significantly higher total fluid intake compared to people without dental erosion.

In highly developed countries, too little water intake (ingested with liquids) is observed. It was estimated that only $51 \%$ of all adults from different countries met the EFSA recommendations for the adequate daily intake (AI - Adequate Intake). In Poland, the UK, Japan and Argentina, a higher share of hot drinks consumption was observed in comparison to other countries participating in the study [12].

The TNS Polska research carried out in June 2015 concluded that the recommended amount of fluids by EFSA (i.e. 1.6 litres per day for women and 2 litres for men) is drinking by only $41 \%$ of Polish women and $22 \%$ of Polish men. When it comes to the ingested fluids, as many as $43 \%$ of the daily intake consist of hot liquids with added sugar, whereas water is only $28 \%$, while - according to the recommendations - the latter's share in the liquid consumption structure should amount to $60-80 \%$ [31].

In studies on the nutritional behaviour of adults and elders, Suliga revealed that over $42 \%$ of all subjects consumed not more than 1 litre of fluids a day, another $36 \%$ - no more than 1.5 litres of fluids [32].

The report prepared by KPMG presents data on the growing consumption of non-alcoholic beverages in Poland, such as sweetened carbonated and non-carbonated beverages, as well as $100 \%$ fruit and vegetable juices, or isotonic beverages. The report underlines that in 2015 the value of the non-alcoholic beverages market in Poland was around 21.7 billion, while an increase of over $14 \%$ is expected by 2020. Taking into account the value of sales, these days carbonated beverages constitute the largest segment of this market. However, the consumers' interest in these drinks is predicted to be declining due to the desire to implement the principles of a healthy lifestyle; the authors of the report point out this may lead to an increase in the consumption of isotonic beverages [33]. 
In a study conducted among patients of dental practices in Kraków, statistically significant differences were observed between persons with dry mouth and dental erosion. Assessment of dry mouth as part of own study was based on the result of the mirror test, supplemented with subjective answers to the questionnaire, and therefore did not include the analysis of the actual amount of salivary secretion, its structure or chemical composition. People who declared experiencing dry mouth also took more fluids daily. Of the total number of respondents, $12.9 \%$ indicated that they usually have dry mouth in the morning. This may be related to the consumption of alcoholic beverages, which was not asked in this study.

For example, among alcohol-dependent people undergoing the detoxification programme, a high prevalence and a low level of severity of erosion lesions were determined based on BEWE [34].

In the deliberately selected group of adolescents and adults (118 persons aged 13-30), who declared frequent consumption of cola drinks, the relationship between consumption of these beverages and the use of other stimulants such as coffee, tea, alcohol, energy drinks and cigarettes was assessed by structural equation modeling. The consumption of cola-type drinks had a direct impact on alcohol consumption in the $20-30$ age group. The consumption of energy drinks directly influenced the alcohol consumption of young people and the smoking of cigarettes by young adults [35]

In the group of students of the Academy of Physical Education and performers from folk groups of song and dance aged 20-30, everyone declared knowledge of the properties and effects of energy and isotonic drinks, but no-one linked the consequences of their consumption with damage to enamel [36].

Of the total number of young adults included in a Danish study, 15.8\% declare that they consume energizing drinks once a week. Men have a higher frequency of consumption compared to women. The results of this study indicate that young age, being professionally active and low level of education are related to the frequency of consumption of energy drinks. Selected health behaviours, i.e. daily smoking, excessive alcohol consumption and being overweight are related to the frequency of energy drinks consumption [37].

Some researchers emphasize that the influence of acids derived from food on the formation of erosive lesions is not direct, because it is modified by such factors as: structure and anatomy of teeth, soft tissue structure, swallowing method and composition of saliva [38].

The clearly negative impact of carbonated beverages, i.e. pepsi-type, fruit juices (e.g. mango juice) and coffee on hard tissue mineralization was confirmed in a study by Hans et al., which investigated the effect of these beverages on saliva $\mathrm{pH}$ and the rate of its secretion, among 120 persons qualified for the examination on the basis of strict inclusion and exclusion criteria. It was shown that the most $\mathrm{pH}$-lowering drink immediately after consumption was Pepsi (from $\mathrm{pH}=7.18$ to $\mathrm{pH}=5.65$ ). At the same time, it was emphasized that the total clearance (clearance coefficient) of the oral cavity after consump- tion of this drink was about 13 minutes. However, after consuming fruit juice and coffee (despite a smaller drop in $\mathrm{pH}$ ) - the clearance amounted to about 15 minutes. It was also indicated that despite the fact that the oral cavity cleared up quite quickly due to the increase in salivation, the tested beverages show strong erosive properties [39].

Research on diet-related factors affecting the formation of erosive lessions focuses not only on the type of food or liquid intake, but also on the way they are consumed. It is emphasized that drinking through a straw reduces the risk of erosion [4].

The occasional drinking through the straw concerned fewer than $22 \%$ of the studied adults attending dental practices in Kraków.

In the work of Kaczmarek and Sołtan, conducted in a group of 162 people aged 18-80, including 100 people with newly diagnosed reflux disease, the occurrence and severity of erosive lesions were determined according to the Lussi index. In the healthy group (mean age 38.8 years) the occurrence of erosion concerned $25.8 \%$. Frequency and severity of erosion were significantly higher among patients with reflux disease in relation to healthy people. Daily consumption of acidic drinks was declared by $43.5 \%$ of healthy people and $46 \%$ of patients (differences not statistically significant). Sometimes drinking sour drinks through a straw reported $35.5 \%$ of healthy people and $28 \%$ of people with the gastro-esophageal reflux. It is interesting how the respondents understood the term 'acidic' drinks and foods. There were no significant differences in the frequency of consumption of acidic products between sick and healthy people [40].

In the presented work, limitations in the interpretation of results may result from the small size and specificity of the study group. People who come in for dental checkups have a basic knowledge of oral hygiene and are interested in the health condition of their teeth, which is also associated with their level of education. In the presented study, slightly more than half of the respondents have higher education, and $40 \%$ have secondary education.

\section{Conclusions}

Non-carious lesions of hard tissues seem to be a significant health problem for more than a third of adults in Kraków who attend dental practices.

The subjects under examination show unsuitable nutritional behaviours concerning the quality and quantity of selected non-alcoholic beverages, which may contribute to erosive defects.

It is recommended that further research be conducted in the field of the etiopathogenesis of erosion and the frequency of its occurrence in connection with the consumption of fluids and foods in Polish society, due to the growing epidemiological significance.

The authors of the study kindly thank the dentists and dental assistants from the dental practices participating in the study for assessing the occurrence of dental erosion and dry mouth and help in collecting research material for this study. 


\section{References}

1. American Dental Association; http://www.ada.org/en/ member-center/oral-health-topics/dental-erosion (accessed:15.10.2018).

2. Hicks J., Garcia-Godoy F., Flaitz C., Biological factors in dental caries enamel structure and the caries process in the dynamic process of demineralization and remineralization (part 2), “J. Clin. Pediatr. Dent.” 2005; 29 (2): 119-124.

3. Hara T.A., Carvalho C.J., Zero T.D., Causes of dental erosion: Extrinsic factors, in: Amaechi B.T. (ed.), Dental Erosion and its Clinical Management, Springer International Publishing, Switzerland 2015: 69-96.

4. Carvalho T.S., Colon P., Ganss C., Huysmans M.C., Lussi A., Schlueter N., Schmalz G., Shellis R.P., Tveit A.B., Wiegand A., Consensus report of the European Federation of Conservative Dentistry: Erosive tooth wear - diagnosis and management, "Med. Prakt. Stomatol." 2015; 4: 17-22.

5. Olczak-Kowalczyk D., Jackowska T., Czerwionka-Szaflarska M., Książyk J., Szostak-Węgierek D., Kaczmarek U., Guidelines of Polish experts regarding the nutrition rules of children and adolescents in the aspect of dental caries prevention, "Nowa Stomatol." 2015; 20 (2): 81-91.

6. Stasiuk E., Przybyłowski P., Electrochemical quality indicators in evaluation of isotonic beverages, "Prob. Hig. i Epidemiol." 2015; 96 (4): 827-829.

7. Całkosiński I., Dobrzyński M., Herman K., Kowalczyk-Zając M., Czajczyńska-Waszkiewicz A., Fita K., Parulska O., The influence of diet on the formation of non-carious hard dental tissues lesions - literature review, "Piel. Pol." 2014; 4 (54): 325-331.

8. Moynihan P., Petersen P.E., Diet, nutrition and the prevention of dental diseases, "Public Health Nutrition" 2004; 7 (1A): 201-226.

9. Kaczmarek U., Harłukowicz K., Frequency and determinants of dental erosion prevalence in children and adolescents, "Nowa Stomatol." 2014; 2: 100-109.

10. Pawlik A., Almost all about the tooth enamel erosion - the result of civilisation; http://stomatologianews.pl/erozji-szkliwa-zebowego-ubocznym-skutku-cywilizacji/ (accessed: 28.03.2019).

11. De Almeida P., Grégio A.M., Machado M.A., de Lima A.A., Azevedo L.R., Saliva composition and functions: A comprehensive review, "The Journal of Contemporary Dental Practice" 2008; 9 (3): 072-080.

12. Martinez H., Guelinckx I., Salas-Salvado J., Gandy J., Kavouras SA, Moreno LA., Harmonized cross-sectional surveys focused on fluid intake in children, adolescents and adults: The Liq.in initiative, “Ann. Nutr. Metab.” 2016; 68 (suppl. 2): 12-18.

13. Marcinkowska U., Gałeczka M., Kukowka K., Kania M., Lau K., Jośko-Ochojska J., Changes in beverage consumption among youth, "Prob. Hig. Epidemiol." 2014; 95 (4): 907-911.

14. Błaszczyk E., Piórecka B., Jagielski P., Prusak A., SchlegelZawadzka M., The relationship between the consumption of functional beverages and the use of other stimulants by high school students in Poland, "Med. Int. Rev." 2015; 4 (105): 208-213.
15. Puri K.S., Suresh K.R., Gogtay N.J., Thatte U.M., Declaration of Helsinki, 2008: Implications for stakeholders in research, "J. Postgrad. Med." 2009; 55 (2): 131-134.

16. World Health Organisation; http://www.euro.who.int/en/ health-topics/disease-prevention/nutrition/a-healthy-lifestyle/body-mass-index-bmi (accessed: 15.07.2018).

17. Kaczmarek U., Xerostomia - aetiology, prevalence and diagnosis - on the basis of literature, "Czas. Stomatol." 2007; 60 (1): 20-31.

18. Walerczyk A., Paszyńska E., Surdacka A., Non-carious tooth loss in terms of erosion - a literature review, "Dental Forum" 2015; 63 (1): 89-96.

19. Bartlett D.W., Lussi A., West N.X., Bouchard P., Sanz M., Bourgeois D., Prevalence of tooth wear on buccal and lingual surface and possible risk factors in young European adults, "J. Dent." 2013; 41 (11): 1007-1013.

20. Strużycka I., Rusyan E., Bogusławska-Kapała A., Prevalence of dental erosion in young adults aged 18 years in Poland, "Przegl. Epidemiol." 2014; 68 (4): 689-693.

21. Kaczmarek U., Sołtan E., Evaluation of dental erosions of Extrinsic and intrinsic origin with use of BEWE Index, "Dent. Med. Probl." 2011; 48 (1): 23-29.

22. Fijał D., Kaczmarczyk-Stachowska A., Knychlska-Karwan Z., Chomyszyn-Gajewska M., Ciesielska M., Gawrzewska B., Kwapińska H., Sendur A., Występowanie ubytków niepróchnicowego pochodzenia $w$ populacji wieku 15-80 lat w Krakowie, "Czas. Stomat." 2001; 54 (10): 636-641.

23. Waszkiel D., Nadżerki nietypowe szkliwa-etiopatogeneza, klinika i zapobieganie w świetle badań własnych [rozprawa habilitacyjna], Akademia Med. Bialostocensis, Białystok 2000.

24. Waszkiel D., Dieta - istotny czynnik w etiologii erozji zębów, "Wiad. Lek." 2004; 57: 647-652.

25. Jarvinen V.K., Rytömaa I.I., Heinonen O.P., Risk factors in dental erosion, "J. Dent. Res.” 1991; 70 (6): 942-947.

26. Li H., Zou Y., Ding G., Dietary factors associated with dental erosion: A meta-analysis, "PLoS One" 2012; 7 (8): e42626.

27. Ostrowska A., Piątowska D., The effect of sports isotonic drinks on the prevalence of erosive lesions in teeth of athletes, "Dent. Forum" 2011; 1: 35-40.

28. Taji S., Seow W.K., A literature review of dental erosion in children, “Aust. Dent. J.” 2010; 55 (4): 358-367.

29. Pegoretti C., Antunes A.E.C., Manchado-Gobatto F., Capitani C.D., Milk: An alternative beverage for hydration, "Food and Nutrition Sciences" 2015; 6: 547-554.

30. Ostrowska A., Piątowska D., Bołtacz-Rzepkowska E., Evaluation of oral hygiene and dietary habits in athletes in terms of dental erosion, "Probl. Hig. Epidemiol." 2013; 94 (2): 253-257.

31. TNS Report; http://www.tnsglobal.pl/coslychac/2015/ 06/18/ile-wody-pija-polacy/ (accessed: 15.10.2018).

32. Suliga E., Health behaviours related to the nutrition of adults and elderly people, "Hygeia Public Health" 2010; 45 (1): 44-48.

33. KPMG, Rynek napojów bezalkoholowych w Polsce; https:// assets.kpmg.com/content/dam/kpmg/pl/pdf/2016/09/pl-Raport-KPMG-Rynek-napojow-bezalkoholowych-w-Polsce. pdf (accessed: 6.09.2017). 
34. Manarte P., Manso M.C., Souza D., FriasBulhosa J., Gago S., Dental erosion in alcoholic patients under addiction rehabilitation therapy, "Med. Oral Patol. Oral Cir. Bucal." 2009; 14 (8): 377-384.

35. Jaworski M., Gustek S., Barcz M., Zwiazek picia napojów typu cola ze stosowaniem używek przez młodziez $i$ młodych dorostych, "Alkoholizm i Narkomania” 2013; 26 (4): 349-364.

36. Joachimiak I., Szołtysek K., Awareness, Knowledge and Frequency of Consumption Energy Drinks and Isotonic Drinks by the Young People, Actively Training Sports, "Nauki Inżynierskie i Technologie" 2013; 1 (8): 26-38.

37. Friis K., Lyng J.I., Lasgaard M., Larsen F.B., Energy drink consumption and the relation to socio-demographic fac- tors and health behavior among young adults in Denmark. A population-based study, "European Journal of Public Health" 2014; 24 (5): 840-844.

38. Tomasik M., Lipski M., Frequency and aetiology of noncarious cervical lesions with pulp exposure, "Annales Academiae Medicale Stetinensis" 2009; 55 (1): 70-78.

39. Hans R., Thomas S., Garla B., Dagli R., Hans M., Effect of Various Sugary Beverages on Salivary pH, Flow Rate, and Oral Clearance Rate amongst Adults, Scientifica 2016; https://www.hindawi.com/journals/scientifica/2016/5027283/ (accessed: 22.05.2017).

40. Kaczmarek U, Sołtan E., Prevalence of exogenous and endogenous dental erosion, "Czas. Stomatol." 2008; 61 (10): 669-678. 